Dikirim: 18 April 2017

Diterbitkan: 1 November 2017

\title{
Paparan pestisida terhadap kejadian penyakit paru obstruktif kronis pada petani di Sumatera Utara
}

\section{Pesticide exposure and incidence of chronic obstructive pulmonary disease among farmers in North Sumatra}

Jernita Sinaga ${ }^{1}$, Nurliyani $^{2}$, Yusrizal Djam'an Saleh ${ }^{3}$

\begin{abstract}
Purpose: This study aims to analyze and describe the risk of exposure to pesticides (age, sex, education, smoking habits, length of service, time of spraying, number of pesticides and personal protective equipment) related to the incidence of COPD to farmers in Barus Jahe, Karo District. Methods: This case control study with a total sample of 90 people, consisting of 45 cases and 45 controls. Samples were taken by simple random sampling. Data analysis was performed using univariable tests, bivariable with Chi-square tests and multivariable with logistic regression. Results: There was a significant correlation between age, gender, education, employment, personal protective equipment to the incidence of COPD, while there was no significant association between the time of spraying, the amount of pesticides and smoking status with the incidence of COPD. The most influential factors on the incidence of COPD is the working period and personal protective equipment. Conclusion: Farmers should always use personal protective equipment and appropriate dosage of pesticide as stated on the packaging label. Public health office also can reduce COPD infections with early detection programs for farmers who are exposed to pesticides every day.
\end{abstract}

Keywords: COPD; pesticides; farmer; sphirometry

\footnotetext{
${ }^{1}$ Departemen Perilaku Kesehatan, Lingkungan, dan Kedokteran Sosial, Fakultas Kedokteran, Universitas Gadjah Mada

(Email: jernitasinaga_74@yahoo.co.id)

${ }^{2}$ Fakultas Peternakan, Universitas Gadjah Mada

${ }^{3}$ Fakultas Kedokteran, Universitas Gadjah Mada
} 


\section{PENDAHULUAN}

Pestisida berguna bagi petani namun dapat menimbulkan dampak negatif (1). Penggunaan pestisida dalam mengatasi masalah serangan hama pada petani di Kecamatan Barus Jahe Kabupaten Karo menunjukkan kecenderungan penggunaan pestisida terus menerus dengan frekuensi tinggi, bahkan tidak jarang kurang memperhatikan aturan pemakaian (2). Petani memiliki kedudukan ganda untuk terjadi keracunan sebagai pelaku dan penderita. Sistem penggunaan pestisida yang tidak tepat sasaran dapat menimbulkan bahaya pada orang lain. Petani akan mengalami ancaman keracunan akibat pekerjaan (3).

Data RSUD Dati II Kabupaten Karo menunjukkan penyakit yang berhubungan dengan paru-paru berada pada urutan ke-4 dengan jumlah pasien tahun 2011 sebanyak 403 pasien dengan 68\% diantaranya adalah penderita saluran pernapasan (Asma Bronchitis dan PPOK) dan 75\% diantaranya tinggal di pedesaan (4).

Keracunan pestisida pada petani terjadi bila peradangan kontak dengan kulit dan membran mukosa (mata, hidung, jalur udara). Paru-paru dapat terekspos pestisida dari udara yang mengandung padatan atau aerosol cair dan uap. Risiko kesehatan sering terjadi selama pengolahan konsentrasi formula, penghirupan aerosol pada pengenceran selama penyemprotan (5). Penelitian di Kecamatan Kaban jahe Kabupaten Karo menemukan 83,5\% petani mengalami keracunan pestisida. Penelitian lain juga menemukan lama kerja dan frekuensi lama penyemprotan berhubungan dengan keluhan kesehatan petani. Proporsi keracunan petani di lima Kecamatan Kabupaten Karo tahun 2007 sebesar 78,3\% (6).

Penggunaan pestisida oleh Dinas Pertanian dan Dinas Kesehatan di Kabupaten Karo dilaksanakan sejak tahun 2004. Kegiatan intensif dilakukan mengacu pada pedoman pengamanan penggunan pestisida khusus untuk petani dan operator pestisida yang dikeluarkan oleh Depkes RI tahun 2003. Namun, belum memberikan hasil maksimal. Terbukti masih ditemukan keracunan pestisida pada petani. Penelitian ini bertujuan mengetahui hubungan besar risiko paparan pestisida terhadap kejadian PPOK di Kecamatan Barus Jahe.

\section{METODE}

Penelitian kuantitatif ini menggunakan rancangan case control dengan pendekatan retrospective, melibatkan 90 orang terdiri dari 45 kasus dan 45 kontrol, sampel diambil dengan simple random sampling.

Kriteria inklusi terdiri 1) bersedia berpartisipasi dalam penelitian; 2) bertempat tinggal tetap di wilayah Kecamatan Barus Jahe Kabupaten Karo; 3) bekerja sebagai petani selama $>3$ tahun dan yang berusia $>30$ tahun, untuk kelompok kasus tercatat sebagai pasien. Variabel bebas adalah umur, jenis kelamin, tingkat pendidikan, kebiasaan merokok, masa kerja petani, waktu penyemprotan, jenis pestisida, penggunaan APD. Variabel terikat adalah kejadian PPOK.

Pemeriksaan faal paru menggunakan uji spirometrik. Pengukuran spirometrik dievaluasi dengan nilai VEP1 pasca bronkodilator $<80 \%$ prediksi serta nilai VEP1/KVP $<0,70$ memastikan ada hambatan aliran udara yang tidak sepenuhnya reversibel. Uji bronkodilator dengan pemberian ventolin inhalasi sebanyak 8 hisapan, 15-20 menit kemudian dilihat perubahan nilai VEP1/APE, perubahan nilai VEP1/APE $<20 \%$ dan $<200 \mathrm{ml}$ dari nilai awal. Hasil spirometrik VEP1 0\% (VEP/KVP) $<70 \%$ berarti PPOK. Kategori menentukan derajat PPOK dengan melihat angka VEP1, bila VEP1 $>70 \%$ dikatakan PPOK ringan, 50-70 \% PPOK sedang, 30-50 PPOK berat, <30 \% PPOK sangat berat (8). Analisis bivariabel menggunakan uji chi-square dan besar risiko dengan odd ratio (OR). Analisis multivariabel menggunakan regresi logistik.

\section{HASIL}

Karakteristik subjek penelitian meliputi umur, jenis kelamin, dan tingkat pendidikan. Distribusi frekuensi disajikan pada Tabel 1 .

Tabel 1. Distribusi frekuensi karakteristik subjek penelitian.

\begin{tabular}{lc}
\hline \multicolumn{1}{c}{ Variabel } & $\begin{array}{c}\mathbf{\%} \\
(\mathbf{n}=\mathbf{9 0})\end{array}$ \\
\hline Umur & \\
30-49 tahun & 42,22 \\
$50-69$ tahun & 22,22 \\
$\geq 70$ tahun & 35,56 \\
Jenis kelamin & \\
Laki-laki & 46,67 \\
Perempuan & 32,28 \\
Tingkat & \\
pendidikan & \\
Tidak taman SD & \\
SD & 0,63 \\
SMP & 39,24 \\
SMA & 25,32 \\
Perguruan tinggi & 31,01 \\
\hline
\end{tabular}


Tabel 2 menunjukkan distribusi frekuensi responden penelitian. Lebih dari 50\% merokok.

Tabel 2. Distribusi frekuensi responden penelitian

\begin{tabular}{lc}
\hline \multicolumn{1}{c}{ Variabel } & Persentase (\%) \\
\hline Masa kerja & \\
3-10 tahun $(\mathrm{n}=14)$ & 15,56 \\
$\geq 10$ tahun $(\mathrm{n}=76)$ & 84,44 \\
Waktu penyeprotan & 6,67 \\
Pagi jam 08.00-10.00 $(\mathrm{n}=6)$ & 30,00 \\
Siang jam 11.00-15.00 (n=27) & 63,33 \\
Sore jam 15.00-18.00 ( $\mathrm{n}=57)$ & \\
Jumlah jenis pestisida & 24,44 \\
$<5$ jenis $(\mathrm{n}=22)$ & 75,56 \\
$\geq 5$ jenis $(\mathrm{n}=68)$ & \\
Pemakaian APD & 47,48 \\
Tidak Lengkap $(<5$ jenis) & \\
(n=43) & 52,22 \\
Lengkap ( $\geq 5$ jenis) $(\mathrm{n}=47)$ & \\
Status merokok & 52,22 \\
Ya $(\mathrm{n}=47)$ & 47,47 \\
Tidak $(\mathrm{n}=43)$ & \\
\hline
\end{tabular}

Lebih dari setengah petani terpapar pestisida mingguan, $46 \%$ terpapar pestisida hampir setiap hari dan hanya 3\% yang terpapar pestisida bulanan. Tabel 3 menunjukkan 57\% petani mengalami keracunan pestisida. Sebanyak 62\% petani lebih memilih untuk istirahat di rumah tanpa pengobatan. Petani lebih banyak melakukan penyemprotan durasi 2-3 jam/hari (70\%). Alat penyemprot pestisida yang digunakan paling banyak adalah spreyken alat penyemprot biasa (63\%) dan hanya 3\% yang menggunakan swingfog. Masih ada $19 \%$ petani yang mencampur dengan menggunakan tangan yang sangat berisiko keracunan.

Tabel 3 menunjukkan umur petani pada kelompok kasus lebih tua daripada kelompok kontro. Umur, jenis kelamin, tingkat pendidikan dan pemakanan APD berhubungan dengan kejadian PPOK pada petani. Sementara masa kerja, jumlah jenis pestisida dan status merokok tidak berkorelasi dengan PPOK petani.
Tabel 3. Hasil analisis bivariabel antara variabel bebas dengan kejadian PPOK

\begin{tabular}{|c|c|c|c|c|}
\hline Variabel & $\begin{array}{l}\text { Kasus } \\
\text { n (\%) }\end{array}$ & $\begin{array}{l}\text { Kontrol } \\
\text { n (\%) }\end{array}$ & $p$ & OR $(95 \% \mathrm{CI})$ \\
\hline \multicolumn{5}{|l|}{ Umur } \\
\hline$\geq 70$ tahun & $26(57,78)$ & $6(13,33)$ & \multirow{3}{*}{0,0001} & $10,64^{*}$ \\
\hline 50-69 tahun & $8(17,78)$ & $12(26,67)$ & & $(3,43-32,96)$ \\
\hline 30-49 tahun & $11(24,44)$ & $27(60,00)$ & & $\begin{array}{r}1,64 \\
(0,525-5,099)\end{array}$ \\
\hline \multicolumn{5}{|c|}{ Jenis kelamin } \\
\hline Laki-laki & $30(66,67)$ & $18(40,00)$ & \multirow{2}{*}{0,01} & 3,00 \\
\hline Perempuan & $15(33,33)$ & $27(60,00)$ & & $(1,169-7,776)$ \\
\hline \multicolumn{5}{|c|}{ Tingkat pendidikan } \\
\hline Rendah & $39(86,67)$ & $26(57,78)$ & \multirow[b]{2}{*}{0,002} & 4,75 \\
\hline Tinggi & $6(13,33)$ & $19(42,22)$ & & $(1,533-16,272$ \\
\hline \multicolumn{5}{|l|}{ Masa kerja } \\
\hline$\geq 10$ tahun & $36(80,00)$ & $40(88,89)$ & \multirow{2}{*}{0,24} & \\
\hline 3-10 tahun & $9(20,00)$ & $5(11,11)$ & & $(0,121-1,861)$ \\
\hline \multicolumn{5}{|c|}{ Waktu penyemprotan } \\
\hline $\begin{array}{l}\text { Sore jam } \\
15.00-18.00\end{array}$ & $13(73,33)$ & $14(31,11)$ & \multirow{3}{*}{0,51} & \\
\hline $\begin{array}{l}\text { Siang jam } \\
11.00-15.00\end{array}$ & $12(26,67)$ & $27(60,00)$ & & $\begin{array}{r}1,85 \\
(0,290-11,90)\end{array}$ \\
\hline $\begin{array}{l}\text { Pagi jam } \\
08.00-10.00\end{array}$ & $2(4,44)$ & $4(8,89)$ & & \\
\hline \multicolumn{5}{|c|}{ Jumlah jenis pestisida } \\
\hline$<5$ jenis & $33(73,33)$ & $35(77,78)$ & \multirow{2}{*}{0,62} & 0,78 \\
\hline$\geq 5$ jenis & $12(26,67)$ & $10(22,22)$ & & $(0,265-2,293)$ \\
\hline \multicolumn{5}{|c|}{ Pemakaian APD } \\
\hline \multicolumn{5}{|c|}{ Tidak } \\
\hline $\begin{array}{l}\text { Lengkap }(<5 \\
\text { jenis) }\end{array}$ & $28(62,22)$ & $15(33,33)$ & \multirow[t]{2}{*}{0,006} & \multirow{2}{*}{$\begin{array}{r}3,29 \\
(1,278-8,584)\end{array}$} \\
\hline $\begin{array}{l}\text { Lengkap ( } \geq 5 \\
\text { jenis) }\end{array}$ & $17(37,78)$ & $30(66,67)$ & & \\
\hline \multicolumn{5}{|c|}{ Status merokok } \\
\hline $\mathrm{Ya}$ & $26(57,78)$ & $21(46,67)$ & \multirow{2}{*}{0,29} & 1,56 \\
\hline Tidak & $19(42,22)$ & $24(53,33)$ & & $(0,628-3,910)$ \\
\hline
\end{tabular}

Tabel 4 menunjukkan analisis multivariabel variabel bebas dengan kejadian PPOK pada petani. Model 2 dipilih sebagai model akhir berdasarkan nilai Bayesian Information Criterion (BIC) dan Akaike's Information Criterion (AIC) yang paling rendah. Variabel umur dan jenis kelamin merupakan confounding dari variabel masa kerja (Tabel 4.)

Tabel 4. Hasil analisis multivariabel antara variabel bebas dengan kejadian PPOK

\begin{tabular}{|c|c|c|c|c|c|c|c|c|}
\hline \multirow[t]{2}{*}{ Variabel } & \multicolumn{2}{|r|}{ Model 1} & \multicolumn{2}{|r|}{ Model 2} & \multicolumn{2}{|r|}{ Model 3} & \multicolumn{2}{|r|}{ Model 4} \\
\hline & $\mathbf{P}$ & OR (95\% CI) & $\mathbf{P}$ & OR (95\% CI) & $\mathbf{P}$ & OR (95\% CI) & $\mathbf{P}$ & OR (95\% CI) \\
\hline Masa kerja & 0,004 & $0,06(0,008-0,400)$ & 0,003 & $0,06(0,008-0,377)$ & 0,011 & $0,13(0,029-0,638)$ & 0,129 & $0,34(0,086-1,364)$ \\
\hline $\begin{array}{l}\text { Pemakaian } \\
\text { APD }\end{array}$ & 0,005 & $5,82(1,710-19,797$ & 0,005 & $5,82(1,721-19,699)$ & 0,015 & $3,57(1,279-9,952)$ & 0,003 & $4,52(1,698-12,049)$ \\
\hline Umur & 0,000 & $1,13(1,061-1,201)$ & 0,000 & $1,12(1,069-1,206)$ & 0,000 & $1,11(1,056-1,169)$ & - & - \\
\hline Jenis kelamin & 0,001 & $8,33(2,279-30-448)$ & 0,001 & $8,84(2,464-31,733)$ & - & - & 0,003 & $4,49(1,660-12,168)$ \\
\hline $\begin{array}{l}\text { Tingkat } \\
\text { pendidikan }\end{array}$ & 0,541 & $1,52(0,395-5,859)$ & - & - & - & - & - & - \\
\hline $\mathrm{BIC}$ & & 105,091 & & 100,966 & & 110,447 & & 123,927 \\
\hline AIC & & 90,0926 & & 88,4667 & & 100,448 & & 113,928 \\
\hline
\end{tabular}




\section{BAHASAN}

PPOK merupakan salah satu penyakit yang etiologinya berasal dari gene-enviroment interaction (9). Beberapa karakteristik individu sebagai faktor pejamu dan faktor lingkungan saat paparan pestisida harus benar-benar diperhatikan antara lain usia, jenis kelamin, pendidikan, masa kerja, APD dan riwayat kesehatan seseorang, sebagaimana temuan hasil penelitian ini.

Penelitian ini menemukan hubungan umur dengan kejadian PPOK. Petani lebih dari umur $>70$ tahun sebanyak (35,56\%) berisiko 1,12 kali untuk mengalami PPOK. Seseorang dengan bertambahnya umur maka fungsi metabolisme tubuh juga menurun (10-11).

Petani laki-laki 9 kali berisiko PPOK dibandingkan dengan petani perempuan. Petani laki-laki lebih dominan melakukan penyemprotan, sehingga lebih sering terpapar pestisida daripada petani perempuan. Paparan pestisida yang terhirup dalam jumlah yang besar selain terjadi penyakit PPOK dapat juga mengakibatkan kerusakan otak dan ginjal pada orang dewasa serta keguguran pada wanita hamil dan menurunkan fertilitas pada kaum lelaki (12). Kaum wanita rata-rata mempunyai aktivitas kholinestrase darah lebih tinggi di banding dengan laki-laki meskipun demikian tidak dianjurkan wanita menyemprot dengan menggunakan pestisida, karena pada saat kehamilan kadar rata-rata kholinestrase cenderung turun (13).

Subjek penelitian dengan tingkat pendidikan rendah berisiko untuk terjadinya PPOK hampir 5 kali lipat dibandingkan dengan mereka yang berpendidikan tinggi. Tingkat pendidikan sangat berpengaruh karena pada tingkat pendidikan formal yang telah diperoleh seseorang akan memberikan tambahan pengetahuan bagi individu.

Petani dengan masa kerja $>10$ tahun memiliki kemungkinan untuk terjadinya PPOK 94\%. Penelitian sebelumnya membuktikan bahwa masa kerja $>5$ tahun berrisiko gangguan paru. Masa kerja diartikan seberapa lama petani mulai melakukan pekerjaannya sebagai seorang petani. Sehingga semakin lama masyarakat menjadi seorang petani dan terpapar pestisida, maka semakin besar kemungkinan akan terinfeksi PPOK karena terpapar pestisida. Semakin sering petani melakukan penyemprotan pestisida, maka semakin besar pula kemungkinan risiko terjadinya keracunan pestisida (16).

Masalah paling berbahaya pada paparan pestisida adalah terhirupnya sisa debu, uap dan gas yang dikeluarkan pestisida pada saat meracik maupun proses penyemprotan dapat menyebabkan pneumonitis, pembengkakan paru-paru (pulmonary edema) dan kematian, semakin banyak sisa racun pestisida yang terhirup oleh seseorang akan semakin tinggi kandungan racun dalam tubuh bagi orang dewasa bila kelebihan zat racun mengakibatkan system persarafan yang abnormal (neuropathy) dan atau kronik nephrophathy (17).

Partikel $\geq 5$ mikron akan mengendap di hidung, nasofaring, trakea dan percabangan bronkus. Partikel $\leq 2$ mikron akan berhenti di bronkiolus respiratorius dan alveolus. Partikel $\leq 0,5$ mikron biasanya tidak sampai mengendap di saluran pernapasan akan tetapi akan dikeluarkan lagi. Partikel bersama polutan seperti bahan kimia dari pertanian hasil reaksi dari pestisida akan menimbulkan penurunan faal paru, sedangkan partikel saja tidak menimbulkan gangguan faal paru pada orang normal. Gangguan faal paru yang terjadi adalah penurunan FEV1 dan rasio FEV2/FVC, yaitu gangguan obstruksi saluran napas (18).

Paparan pestisida mengakibatkan kerusakan alveolus, elastisitas hilang, sehingga ekshalasi kurang efisien. Kondisi jangka panjang terjadi penimbunan partikel debu bahan kimia pada jaringan paru sehingga terjadi fibrosis atau pneumoconiosis (19).

Lebih dari $75 \%$ petani menggunakan jumlah jenis pestisida $>5$ jenis. Semua responden menggunakan pestisida jenis insektisida, fungisida, herbisida dan rodentisida. Efek toksik pestisida sangat dipengaruhi dosis dan jumlah jenis pestisida yang digunakan. Besar dan seringnya suatu zat masuk ke dalam tubuh akan menghasilkan 2 jenis toksisitas, akut dan kronis (20).

Toksisitas pestisida dapat digolongkan, sangat toksik: aldrin, endosulfan, dieldrin, toksik sederhana: Clordane, DDT,lindane, heptaklor dan Kurang toksik: Benzane hexacloride (BHC) (21). Penelitian ini mem-buktikan bahwa jumlah jenis pestisida bukan meru-pakan faktor risiko PPOK. Penelitian ini tidak sejalan dengan Mualim (2002) yang menemukan petani yang menyemprot hama tanaman dengan menggunakan $>3$ jenis pestisida mempunyai risiko terjadi keracunan hampir 5 kali. Pengguna APD tidak lengkap berisiko 6 kali terkena PPOK dibandingkan. Toksisitas pestisida tidak dapat diubah, tetapi risiko keracunan dapat dihindarkan dengan memakai pakaian dan alat pelindung diri (22). 


\section{SIMPULAN}

Dinas Kesehatan Kabupaten Karo belum memberikan hasil maksimal. Hal ini terbukti masih tingginya tingkat keracunan pestisida pada petani. Umur, jenis kelamin, pendidikan, masa kerja, dan APD adalah faktor yang berhubungan dengan PPOK. Faktor dominan yang menyebabkan PPOK adalah masa kerja dan APD.

\section{Abstrak \\ Tujuan: Penelitian ini dimaksudkan untuk menganalisis dan mendiskripsikan besarnya risiko paparan pestisida (umur, jenis kelamin, pendidikan, kebiasaan merokok, masa kerja, waktu penyem- protan, jumlah jenis pestisida dan alat pelindung diri) yang berhubungan dengan kejadian PPOK pada petani di Kecamatan Barus Jahe Kabupaten Karo. Metode: Penelitian case control dengan total sampel 90 orang petani, terdiri dari 45 kasus dan 45 kontrol. Sampel diambil dengan Simple Random Sampling. Analisis data dilakukan mengunakan uji univariabel, bivariabel dengan uji Chi-square dan multivariable dengan uji regresi logistik. Hasil: Ada hubungan yang bermakna antara umur, jenis kelamin, pendidikan, alat pelindung diri dengan kejadian PPOK, tidak ada hubungan yang bermakna antara waktu penyemprotan, jumlah jenis pestisida dan status merokok dengan kejadian PPOK. Berdasarkan analisis multivariabel ada hubungan bermakna antara masa kerja dengan kejadian PPOK dan yang paling berpengaruh (dominan) dengan kejadian PPOK adalah masa kerja dan alat pelindung diri (APD). Simpulan: Petani harus selalu menggunakan alat pelindung diri dan dosis pestisida yang sesuai seperti yang tercantum pada label kemasan. Kantor kesehatan masyarakat juga dapat mengurangi infeksi PPOK dengan deteksi dini kepada petani yang terpapar pestisida setiap hari.}

Kata kunci: PPOK; pestisida; petani; spirometrik.

\section{PUSTAKA}

1. Sembel, D.T. Toksikologi Lingkungan. Dampak Pencemaran dari Berbagai Bahan Kimia dalam Kehidupan Sehari-hari. Andi, Yogyakarta; 2015.

2. Subiyakto. Dampak Negatif Penggunaan Pestisida. Jakarta : PT. Intermasa; 1990.
3. Achmadi, U.F. Dasar-dasar Penyakit Berbasis Lingkungan, Rajawali Press, Jakarta; 2013.

4. Dinas Kesehatan Kabupaten Karo, 2011. Profil Kesehatan Kabupaten Karo, Kabanjahe

5. Hernandez AF. Pesticide and ashtma; 2011. http://www.medscape.com. access, 10 November 2016, Yogyakarta

6. Dinas Kesehatan Kabupaten Karo. Profil Kesehatan Kabupaten Karo, Kabanjahe; 2007.

7. Murti, B. Struktur Riset, Matrikulasi Program Studi Doktoral, Fakultas Kedokteran UNS. Surakarta; 2011.

8. PDPI. Penyakit Paru Obstruktif Kronik (PPOK), Pedoman Diagnosis dan Penatalaksanaan di Indonesia, Perhimpunan Dokter Paru Indonesia, Jakarta; 2003.

9. Janice dan Rasyid. Laporan Kasus Penyakit Paru Obstruktif Kronis (PPOK), Departemen Ilmu Penyakit Paru \& Kedokteran Respirasi USU, FK USU, Medan - Sumatera Utara; 2010.

10. IARC. Occupational Expousures Insectisida Application And Some Pesticides, WHO., Geneva; 1991.

11. Malaka, T. Kesehatan Kerja dan Penyakit Akibat Kerja, Pengurus Pusat Ikatan Dokter Kesehatan Kerja Indonesia, Jakarta; 1994.

12. Wright, L.F, R.P. Saylor dan F.A. Cecer. Occult Lead Intoxication in Patients with Gout and Kidney Disease. The Journal of rheumatology. Geneva; 1984.

13. Cochrum, K.C. Biokimia (Review of Physiological Chemistry), dalam Harper, H.A. EGC UI, Jakarta; 1980. Chap. 5, 6, 7, 13, 14

14. Global Initiative for Chronic Obstructive Lung Disease (GOLD). Global Strategy for the Diagnosis, Management, and Prevention of Chronic Obstructive Pulmonary Disease. USA, MCR VISION,Inc; 2010.

15. Irianto, K. Ilmu Kesehatan Masyarakat (Public Health), Alfabeta Bandung; 2014.

16. Nasruddin. Faktor-Faktor yang Mempengaruhi Terjadinya Keracunan Pestisida pada Petani Hortikultura di Sukoharjo Tahun 2001. Tesis Pascasarjana Universitas Gajah Mada, Yogyakart; 2001.

17. Khader, A. Systemic Effect in COPD. J. Pulmon. 2007;9(1): 1-3, Jakarta.

18. Syamsiah, A dan Yusnus, F. Pemeriksaan Spirometri Collins, J. Respir Indo. 1997;17 :45-51, Jakarta

19. Soemitrat, J. Epidemiologi Lingkungan, Edisi ketiga, Gadjah Mada University Press. Yogyakarta; 2015.

20. Priyanto Toksikologi Mekanisme, Terapi, Antidotum, dan Penilaian Risiko, Leskonfi, Depok. 2010.

21. ATSDR. Agency for Toxic Substances and Disease Registry. Toxicological Profile for DDT, DDE, and DDD. Prepared by Syracuse Research Corporation Under Contract Number 205-1999-00024 for U.S. Department of Health and Human Services, Public Health Service, Agency for Toxic Substances and Disease Registry; 2002.

22. Fishel, Personal Protective Equipment for Working With Pesticides, University of Missouri-Colombia; 2010. 
